\title{
ФОРМИРОВАНИЕ И ИСПОЛЬЗОВАНИЕ СТРАХОВОГО ФОНДА В СИСТЕМЕ ПЕНСИОННОГО СТРАХОВАНИЯ
}

\author{
(c) 2019 Петров Александр Михайлович \\ доктор экономических наук, профессор Департамента учета, анализа и аудита \\ Финансовый университет при Правительстве Российской Федерации \\ 125993, г. Москва, Ленинградский пр-т, д. 49 \\ E-mail: palmi@inbox.ru \\ (c) 2019 Шнайдер Ольга Владимировна \\ кандидат экономических наук, доцент Департамента учета, анализа и аудита \\ Финансовый университет при Правительстве Российской Федерации \\ 125993, г. Москва, Ленинградский пр-т, д. 49 \\ (c) 2019 Фролова Вероника Александровна \\ доцент кафедры Экономики судостроительной промышленности \\ Санкт-Петербургский государственный морской технический университет \\ 190121, г. Санкт-Петербург, Ленинский пр., 101
}

В статье приведен обзор теоретических подходов к определению понятия страховой фонд, проанализированы взгляды отечественных ученых на страхование как экономическую категорию. Автор делает предположение об актуальности расширения сберегательной функции до инвестиционно-сберегательной с усилением контроля за использованием средств страхового фонда в системе пенсионного страхования.

Ключевые слова: страхование, страховой фонд, функции страхования.

Экономическая природа страхования такова, что оно выступает как необходимый элементом стабилизации производственных отношений в обществе. На современном этапе страхование занимает важное место в финансовой системе. Страхование обеспечивает современному обществу гарантию восстановления имущественных интересов, которые нарушаются разного рода социальными, природными и техногенными явлениями.

Теоретические подходы к исследованию проблем и особенностей современного страхования позволяют определять страхование как механизм возмещения ущербов от событий различной природы, как способ укрепления финансов государства, как стабилизатор финансов граждан и хозяйствующих субъектов. Эволюция экономических отношений определила место страхования в совокупности социально-экономических как инструмент обеспечения устойчивости общественного воспроизводства. Страхование, по мнению большинства авторов, это «экономическая категория, совокупность форм и методов формирования целевых денежных фондов и их использования для возмещения ущерба при различных неблагоприятных яв- лениях, обеспечивающая помощь гражданам и (или) их семьям при наступлении определенных событий в их жизни (дожития, смерти, травмы, инвалидности и т.д.)» [4].

Основополагающим элементом финансового механизма пенсионного страхования выступают пенсионные права граждан, выражающиеся в получении пенсионного обеспечения. Пенсионная система Российской Федерации предполагает три формы пенсионного обеспечения;

- государственное пенсионное обеспечение;

- обязательное пенсионное страхование;

- негосударственное (дополнительное) пенсионное обеспечение.

Обязательному пенсионному страхованию и негосударственному пенсионному страхованию присущи страховые принципы. Государственное пенсионное страхование призвано обеспечить эквивалентность доходов и расходов, гарантирует участникам системы обязательного пенсионного страхования возможность реализации пенсионных прав, приобретенных в рамках системы.

Эффективность пенсионной системы выра- 
жается в оценке соотношения положительного эффекта от ее функционирования и затрат, понесенных для ее обеспечения. На современном этапе пенсионное страхования имеет свой целью обеспечение социальной функции государства с одной стороны, что заключается в обеспечении минимальных гарантий достойного уровня жизни всех пенсионеров, и формирование элементов персональной справедливости посредством повышения зависимости размера пенсии от заработной платы конкретного гражданина, с другой стороны.

Вопросы формирования и распределения ресурсов пенсионной системы, исключившей для себя принцип солидарной ответственности поколений как единственно возможный, следует рассматривать в контексте особенностей формирования и распределения страхового фонда.

Рассмотрим обязательный элемент общественного воспроизводства - страховой фонд. «С помощью страхового фонда во многом разрешается объективно существующее противоречие между человеком и природой, между природой и обществом. Одновременно обеспечивается непрерывность процесса общественного воспроизводства. Разрешение указанного противоречия, однако, не устраняет зависимости человека от стихийных сил природы» [5].

«Теоретические аспекты функционирования страхового фонда концентрируются вокруг основного вопроса страхования - о природе страхового риска. По современным научно-теоретическим представлениям страховой фонд - это средства, изъятые из национального дохода и совокупного общественного продукта. В целом абсолютный размер страхового фонда указывает на размер потерь, которые несет общество в результате ущерба, покрываемого страхованием» [5].

Природа страхового фонда определяется его функционалом, который ограничен сферой материально-производственной деятельности. Потенциал страхового фонда заключается в его роли в обеспечении экономического прогресса на всех уровнях экономических отношений: государство, предприятие, домашнее хозяйство. Ресурсы, аккумулируемые в страховых фондах, обеспечивают не только реализацию ключевой функции страхования - покрытие последствий проявления рисков, сбережения средств, но и служат источником инвестиций в экономику. Наибольшее значение инвестиционный потен- циал страхования приобретает в накопительных видах страхования.

Теоретической базой страхования служат результаты таких наук как экономика, статистика, теория вероятностей. Особой областью знания выступает актуарная математика, имеющая для страхования прикладной характер в части оценки рисков, построения математических моделей, расчета цен на страховые услуги тарифов, управления страховым фондом).

Оперируя большими массивами данных, изучая в ретроспективе и и формируя прогнозы по событиям, составляющим объект страховой защиты, специалисты аккумулируют и анализируют информацию с тем, чтобы выработать оптимальную стратегию.

«Экономика страхования начала формироваться в современном качестве в XIX в. и значительные разработки в теории страхования можно найти во французской литературе. Среди авторов следует выделить А. Курси (1862), Е. Ребу (1863), Е. Абу (1865), которые отошли от юридической точки зрения на страхование как на договор и стали его рассматривать как экономическое явление и вид хозяйственной деятельности. В Германии в это время по теории страхования было едва ли ни единственное сочинение Е. Германа о страховании с экономической точки зрения. Теоретическим базисом страхования традиционно считается амортизационная теория страхового фонда и теория рисков, базирующаяся на теории вероятности и актуарных расчетах. Рассмотрим данные теории в исторической ретроспективе.

В индустриально развитых странах Западной Европы, в США и Японии теоретические аспекты функционирования страхового фонда концентрируются вокруг основного вопроса страхования - о природе страхового риска и рисковых обстоятельств, сопровождающих этот риск. По современным научно-теоретическим представлениям страховой фонд - это средства, изъятые из национального дохода и совокупного общественного продукта. В целом абсолютный размер страхового фонда согласно этим представлениям указывает на размер потерь, которые несет общество в результате ущерба, покрываемого страхованием» [4].

Позиции ряда авторов (Гварлиани Т.Е., Балакирева В.Ю. Шахов В.В.) выражают, что результаты деятельности и затраты в страховании отличаются от прочих затрат и результатов не 
только производственных предприятий, но и финансовых институтов. Подчиняясь общим экономическим законам страховая отрасль предоставляет услуги по формированию страховых резервов для покрытия последствий проявления рисков, а не совершает приращения стоимости. Страховые резервы формируются как в обязательной, так и в добровольной форме, их источником является национальный доход. То есть страхование отрицательно влияет на национальный доход в фазе формирования страховых резервов, при этом имея положительное экономическое влияние при их использовании.

Ключевой функцией страхования является обеспечение снижения отрицательных последствий проявления биологической, социальной и технологической сферы на экономику в целом и ее субъектов. Страхование нивелирует последствия циклических кризисных явлений, спадов деловой активности, используемых технологий, неэффективных инноваций, в том числе природных катастроф, обеспечивая безопасность жизнедеятельности человека. То есть, страхование, оставаясь затратным институтом, имеет положительное значение для общества, что делает его стратегически важной отраслью экономики.

Профессор Д.С. Моляков, основываясь на сложившейся в 70-х годах прошлого века систему классификаций отраслей народного хозяйства, отмечал, что страховые организации ведут деятельность в рыночных условиях и нет оснований выделять их в отдельное звено финансов предприятий и организаций. Данный рудиментарный подход вытесняется на современном этапе утверждениями о том, что страхование является экономической категорией.

Ряд исследователей, в частности В.В.Глущенко, полагают что «...страхование не только освобождает бюджет от расходов на возмещение убытков при наступлении страховых случаев, но является одним из основных источников долгосрочных инвестиций» [2].

Полагаем, что авторы не совсем корректно сформулировали связи бюджета и страхования. Страхование не освобождает «...бюджет от расходов на возмещение убытков при наступлении страховых случаев...», а выступает как самостоятельный страховой резерв, целью формирования которого является стабилизация экономических систем на всех уровнях. Вместе с тем, то, что страхование выполняет главную функцию финансовых институтов - инвестиционную в различных временных интервалах, а не только в форме долгосрочных инвестиций не вызывает сомнений [4].

Наряду с финансами страхование представляет собой самостоятельную экономическую категорию, что определяет наличие у него специфических, присущих только страхованию функций и механизма функционирования. Рейтман Л.И. к функциям, присущим страхованию, отнес рисковую функцию, сберегательную функцию и предупредительную функцию. Соглашаясь с мнением Рейтмана Л.И., расширим функцию сбережения, придав ей логическую инвестиционную завершенность, в рамках модели кругооборота и сегодняшнего понимания системы национальных счетов.

Функции страхования по мнению Шахова В.В. включают в себя функцию формирования специализированного страхового фонда, функцию возмещения ущерба и личное материальное обеспечение граждан, функцию предупреждения страхового случая и минимизация ущерба.

Сберегательная функция, по Рейтману Л.И. и его зарубежных коллег, только в литературных источниках рассматривалась как возможно инвестиционная. На практике же страховая отрасль традиционно использует свою важную инвестиционную составляющую не на прямую, а косвенно через различных финансовых посредников [4]. Исследования финансовых рынков в разных интервалах демонстрируют высокую доходность инвестиций в отрасли и технологии, генерирующие значительные риски техногенного и экологического характера. Тяжесть их прямых и косвенных последствий, зачатую, существенно превышает доходность, полученную в предыдущих периодах.

Таким образом, страхование, целью которого является снижение не только последствий рисков (рисковая функция), но и снижение рисков (превентивная функция) на современном этапе не демонстрирует контрольных функций в отношении инвестирования, что порождает неэффективное использование страховых фондов, создает опасность финансирования риска, а не на предупреждение его.

Рациональное использование и распределение средств страховых фондов наравне с эффективным их формированием является фактором, определяющим соответствие государственных пенсионных обязательств страховым пенсионным правам граждан. 


\section{Библиографический список}

1. Гварлиани Т.Е., Балакирева В.Ю. Денежные потоки в страховании. Москва. 2004. 336 с.

2. Глущенко В.В. Управление рисками. Страхование. Московская обл. 1999. 334c.

3. Рейтман Л.И., Коломин Е.В., Плешков А.П. и др.; Страховое дело: учебник / Под ред. Рейтмана Л.И. Москва. 1992.524 c.

4. Фролова В.А. Методы государственного регулирования экологического страхования в Российской Федерации: дис... канд. экон. наук. 08.00.10/В.А. Фролова. СПб., 2009.

5. Шахов В.В. Страхование: учебник для вузов. Москва. 2003. 311 с.

Поступила в редакцию 14.01.2019 